\title{
Sitoutuminen, sopeutuminen ja vastarinta julkisella sektorilla 1990-luvulla
}

\author{
Karin Filander
}

\begin{abstract}
Aikuisuus on muuttunut elinikäisen oppimisen yhteiskunnassa kypsästä ja valmiista aikuisuudesta jatkuvan keskenkasvuisuuden ja jatkuvan keskeneräisyyden hyväksymiseksi, toteaa Karin Filander lektiossaan.
\end{abstract}

\author{
Mutta ketkä ovatkaan konnia ja ketkä sankareita, kun \\ julkinen sektori kääntää kurssiaan kohti uusliberalismin, \\ yksilöitymisen ja epävarmuuden aikaa?
}

$\mathrm{U}$ lrich Beckin $(1995,26)$ mukaan aikamme ihmisille on tyypillistä jatkuva rajoilla liikkumisen ja epävarmuuden kokemus, joka on muuttunut eräänlaiseksi yksilön elämää määrittäväksi peruskokemukseksi. Ihmiset kokevat olevansa yksin merkityksellistämässä elämäänsä ilman traditioiden tai ryhmäspesifisten merkityslähteiden, kuten yhteiskuntaluokan, ammattiryhmän, paikallisyhteisön, uskonnon tai perheen tuomaa tukea. Näiden tukipisteiden avulla teollisessa yhteiskunnassa määriteltiin identiteettiä ja tuotettiin perustaa moraalisille ratkaisuille (Alheit 1996, 31). Traditioiden mureneminen on johtanut siihen, että jokainen yksilö joutuu tekemään itse omat valintansa, joiden avulla hän hakee paikkaansa ja jatkuvuuksia elämäänsä.

Kasvava joukko ihmisiä joutuu elämään tilapäisten työsuhteiden varassa, mihin liittyy lähes säännöllisesti myös työttömyyskausia. Työelämässä eletään jatkuvien mullistusten, uudelleen organisointien ja toiminnan tehostamisen keskellä, mikä vaikuttaa työpaikan ilmapiiriin ja yhteisöllisyyden kokemuksiin. Työelämän ulkopuolisille elämänpiireille, perheelle ja ystävyyssuhteille jää yhä vähemmän aikaa ja energiaa, koska työ vie kasvavassa määrin voimavaroja. Tällaisessa tilanteessa on vaikeaa löytää sosiaalisia yhteisöjä ja tiloja, joissa yksittäinen henkilö voisi merkityksellistää elämäänsä. Yksilöt joutuvat itse suunnittelemaan, laatimaan, sovittamaan, parsimaan ja paikkaamaan omat elämäkertansa (Beck 1995, 27).

$\mathrm{O}$ ppimisesta ja tiedosta on tullut keskeinen asia, jota tarjotaan ratkaisuksi kaikenlaisiin sosiaalisiin, taloudellisiin ja kulttuurisiin ongelmiin. Oppimisen sanasto on levittäytynyt kasvatustieteestä, psykologiasta, aikuiskasvatuksesta ja filosofiasta myös taloustieteisiin, työmarkkinatutkimukseen, liiketalous- ja markkinatutkimukseen. Tämän levittäytymisen myötä oppimisen sanastosta on tullut vakavasti otettavaa puhetta (Card 1995), jota ei voi enää sivuuttaa millään 
inhimillisen vuorovaikutuksen alueella. Vakavaksi puhetta voidaan nimittää silloin, kun se on muuttunut vallitsevaksi kulttuuriseksi puhetavaksi, joka vaikuttaa siihen, miten asioita perustellaan ja miten niitä oikeutetaan (mt., 68-69).

Oppimispuhe on saavuttanut tällaisen vakavan puheen aseman. Se vaikuttaa kansainvälisessä vuorovaikutuksessa elinikäisen oppimisen, osaamisyhteiskunnan, tietoyhteiskunnan ja jopa talouden osaamisaikakauden käsitteiden kautta. Organisaatiot ja yritykset samaistuvat oppiviksi organisaatioiksi, jotka merkityksellistävät toimintansa yhteistyön ja konsensuksen maailmaksi. Oppivasta organisaatiosta puuttuvat kaikki sellaiset hankalat asiat, kuten intressiristiriidat, linjavalinnat ja kiistely ja neuvottelu vallan ja vaikuttamisen mahdollisuuksista. Elinikäisen oppimisen vaatimus kohdistuu kaikkiin yksilöihin, joiden on tehtävä omat elämänvalintansa. Ihmisten odotetaan olevan kykeneviä ja itseohjautuvia aikuisia oppijoita, jotka pystyvät vastaamaan aina uusiin haasteisiin.

$\mathrm{T}$ utkimukseni liittyy tähän yksilöitymisen, markkinaehtoisen kehittämisen, oppimispuheen ja epävarmuuden aikaan. Tarkastelen erityisesti julkisen sektorin ammattilaisten, virkamiesten ja kehittäjien avaamista näkökulmista 1990-luvun suomalaisen julkisen sektorin kulttuurista murrosta. Julkista sektoria Suomessa on muiden OECD-maiden tavoin määritelty uudelleen yksityiseltä sektorilta johdettujen sanastojen, merkitysjärjestelmien ja niiden avaamien kielikuvien ja identiteettien kautta. Tavoitteenani oli selvittää, miten ammattilaiset, virkamiehet ja kehittäjät tekevät puheensa avulla muutosta ja miten he ylläpitävät toimintansa jatkuvuuksia. Pyrin myös kehittämään uutta metodologista ja metodista lähestymistapaa muutoksen tutkimiseen. Puhe ei tässä lähestymistavassa ole "pelkkää retoriikkaa" vaan puhe otetaan vakavasti ja ymmärretään puhetekoina, joiden avulla toimijat paikantavat itseään ja rakentavat sitä todellisuutta, jonka keskellä he elävät.

Kun esimerkiksi julkisen sektorin ammattilaiset ja virkamiehet ovat tähän saakka sitoutuneet hyvinvointivaltiolliseen moraalijärjestelmään
(Lehto 1991, 183), joka korostaa julkisen sektorin työntekijöiden vastuuta kansalaisten hyvinvoinnista, muuttuu tilanne markkinakäänteen olosuhteissa. Hyvinvointivaltion ammattilaisten vastuunkannon eetos on markkinapuheen hallitsemassa keskustelussa ja puheessa käsitteellistetty kansalaisten holhoamiseksi ja valvonnaksi, jolta puuttuu oikeutus. Kansalaisuuteen liittyvä sosiaalinen sopimus on kulttuurisessa murroksessa korvautumassa asiakkaan kanssa tehtävällä markkinasopimuksella (Pollitt \& Bouckaert 1995, 6).

Tunnistin haastattelemieni henkilöiden puheesta erilaisia menneisyyden, nykyisyyden ja tulevaisuuden kulttuurisia puhetapoja, jotka elävät puheessa vielä rinnakkain. Hämmentävässä murrostilanteessa julkisen sektorin työntekijöiden on vaikea paikantaa itseään ja määrittää itselleen, millainen työ on oikeaa ja oikeutettua työtä julkisella sektorilla. Tarkastelen tätä toiminnan arvolähtökohtia koskevaa kulttuurista murrostilannetta eräänlaisena murtovesiaikana, joissa perinteiset kertomukset ja niiden edustamat identiteetit sekoittuvat uusiin markkinaorientoituneisiin identifioitumisen tapoihin ja kertomuksiin.

$\mathrm{P}$ äaineistona tutkimuksessa on haastatteluaineistot vuosilta 1991, 1992 ja 1997. Haastattelemani henkilöt osallistuivat taloudellisen laman murrosvuosina 90-luvun alussa parivuotiseen työtieteelliseen koulutusohjelmaan. Ohjelman tarkoituksena oli tukea osanottajia heidän työhönsä liittyvissä kehittämishankkeissa. Tavoitteena oli myös luoda ohjelman osanottajille reflektiivistä tilaa, jossa he voisivat pohtia työelämän laadun ja oppimisen kysymyksiä. Ohjel- 
man 26 osanottajaa toimivat mitä erilaisemmissa asiantuntijatehtävissä eri puolella Suomea sekä valtion että kunnan tehtävissä. Kaikki olivat eri alojen korkeasti koulutettuja ammattilaisia. Suurin osa toimi henkilöstötyön ja henkilöstökoulutuksen tehtävissä. Pienempi osa osanottajista toimi ammattilaisina lääkärin, juristin, opettajan, psykologin, insinöörin tai terveydenhuollon tehtävissä. Kaikki elivät keskellä julkisen sektorin rakenteellisia ja kulttuurisia muutoksia ajankohtana, jolle oli ominaista syvä taloudellinen lama, suurtyöttömyys ja talouden kansainvälistyminen.

Julkisen sektorin rakenteelliset ja organisatoriset uudistukset olivat muuttamassa julkishallinnon ohjausjärjestelmää ja työkäytäntöjä. Tulosjohtamisreformin myötä toiminnan ohjausta koskevaa päätösvaltaa siirrettiin alue- ja paikallistasolle, mikä vaikutti erityisesti keskushallinnon tehtävien uudelleenmäärittelyn tarpeisiin. Entisten keskusvirastojen työtekijöiden piti lyhyessä ajassa löytää toimintaansa kokonaan uudenlainen suunta ja perustelut. Kuntien ja valtion tulojen romahtaminen ja toiminnan uusliberalistiset linjaukset johtivat säästöpolitiikkaan, toimintojen liikelaitostamiseen ja henkilöstön saneeraamiseen. Uusliberalistiset toiminnan linjaukset kyseenalaistivat kollektiivisen vastuunkannon ja suunnitelmallisen yhteiskuntapolitiikan merkitystä. Yksilöllistä pärjäämistä, yrittäjyyttä ja markkinalogiikkaa tarjottiin yhteiskunnan organisoitumisen periaatteeksi. (Clarke \&Newman 1997, Coburn 1999, 151-152. )

\section{Konnat ja sankarit mu u tospuh eis s a}

$\mathrm{T}$ ässä tutkimuksessa analysoin haastattelemieni henkilöiden erilaisia suhteutuksia näihin hallinnon 1990-luvun muutoslinjauksiin ja prosesseihin. Haastatteluista oli helppo löytää sitoutunutta muutospuhetta, jonka avulla kehittäjät tekivät muutosta. Tätä muutospuhetta voi luonnehtia mustavalkoiseksi katkospuheeksi, jonka kärjistävien vastakohtien avulla luotiin suurta hyppyä vanhasta uuteen. Tutkimuksessani olen nimittänyt tämän tyyppisen muutospuheen ke- hittämistyön kauniiksi tarinaksi, jonka tarinarakenteet tarjosivat kehittämistyöhön sitoutuneille henkilöille sankarin ja edelläkävijän toimija-aseman. Roiston ja konnan roolin näissä tarinarakenteissa saivat henkilöryhmät, jotka sitoutuivat esisijaisesti vain oman alueensa ja asiantuntijuutensa kehittämiseen. Kehittämistyön kauniin kertomuksen tarinarakenteissa toimivat siis uudet sankarit ja konnat, jotka käänsivät entiset julkisen sektorin hyveet paheiksi. Sitoutunut kehittäjäpuhe nojautui voimakkaasti normittavaan pitäisi- puheeseen, joka käytti hyväkseen äärimmäisiä ilmaisuja, kuten on pakko, varmasti, ehdottomasti, tietysti tai ei koskaan.

Julkisen sektorin ammattilaisten puheessa elivät myös samanaikaisesti monet kulttuuriset puhetavat. Ammattilaiset saattoivat ensin korostaa rooliaan hallinnolle lojaaleina virkamiehinä ja asiantuntijoina, jotka tekivät työtään sen takia, koska kokivat työn tärkeäksi kansalaisten hyvinvoinnin kannalta. Samassa haastattelussa henkilö saattoi siirtyä uudenlaiseen yrittäjyyspuheeseen, jonka avulla hän korosti joustavuuttaan ja jatkuvaa valmiuttaan siirtyä aina uusiin tehtäviin. Vaikka asiantuntijat eivät olleet valmiita luopumaan tärkeäksi kokemastaan työstä, joutuivat he kuitenkin murrostilanteessa sopeutumaan myös uudenlaiseen yrittäjyyden henkeen ja toimintalogiikkaan.

Löysin haastatteluista myös muutoksen vastakertomuksia ja vastarinnan strategioita, jotka yleensä jäävät muutostutkimuksissa varjoon ja vaille huomiota. Avointa markkinapuheen vastustusta ei haastatteluista löytynyt. Vihjeitä vastarinnan strategioista voi löytää puheesta, jota leimasi huumori ja vetäytyvä neutraalius. Huumorin ja ironian avulla ammattilaiset muodostivat vastakertomuksia, joilla he puolustivat perinteisiä julkisen sektorin arvoja, kuten sosiaalista vastuunkantoa, ammattilaisten roolia kansalaisten asianajajana ja ammattityötä kutsumuksen kaltaisena valintana. Ammattilaisuuteen ja asiantuntijuuteen liittyvä vetäytyvä neutraalius oli yksi vastarinnan strategia. Kehittämistyöhön mukaan meneminen saattoi myös olla paras tapa vastustaa kehittämistyötä ja julkisen sektorin markkinamuutoksen pyrkimyksiä. 
$\mathrm{V}$ aikka muutoksia tutkitaan ja muutoksista puhutaan yleensä hyvin sukupuolineutraalilla tavalla, osoitin tutkimuksessani muutos- ja kehittämistyön sukupuolistuneen luonteen. Naiskehittäjien puhe oli hyvin individualistista minä-puhetta, jonka avulla he pyrkivät erottautumaan muun organisaation alistavista ja sukupuolistuneista odotuksista. Myös johtotehtäviin edenneiden naiskehittäjien menestymisen edellytys näytti olevan jatkuva erottautuminen, jolla he suojelivat asemaansa ja vakuuttavuuttaan. Mieskehittäjien puheesta ei löytynyt vastaavanlaista erottautumisen pyrkimystä, vaan he korostivat me-puheellaan jäsenyyttään johdossa, kehittämisryhmissä ja maskuliinisissa valtaverkostoissa. Naiset tekivät kehittäjän työtään enemmän itsensä varassa ja persoonallaan kuin miehet, jotka pystyivät nojautumaan valtaverkostoihin ja vallitseviin maskuliinisiin käytäntöihin.

Tutkimukseni avaa uudenlaisia metodologisia ja metodisia lähestymistapoja muutoksen tutkimiseen neuvottelun ja kamppailun prosessina. Tarkastelen muutosta suhteessa kulttuurisiin puhetapoihin, joilla toimijat määrittelevät ja nimeävät suhdettaan muutokseen. Näin toimijat käyttävät diskursiivista valtaa, joka vaikuttaa siihen, miten sosiaalinen ja kulttuurinen muutos ymmärretään. Tutkimus purkaa oppimisen ja kehityksen positiivista universaalipuhetta. Se auttaa ymmärtämään, että oppimisen kauniin tarinan sanaston myötä hyväksytään samalla joitakin perusoletuksia muutoksen luonteesta. Oppimisena muutos kytketään ongelmattomalla tavalla kehitykseen ja edistykseen. Muutos voi kuitenkin merkitä myös taantumaa ja toimivien työkäytäntöjen romuttamista. Vallitsevat muutosnäkemykset eivät voi siis koskaan yksin määrittää merkitysrakenteita ja merkitysten muodostumista, vaikka siltä ensi näkemältä näyttäisikin.

Tutkimukseni perusteella voin väittää, että globalisoituvan riskiyhteiskunnan epävarmuuden ajassa tarvitaan aikuiskasvatuksellista toimintaa ja uudenlaisia oppimisen siirtymätiloja, joissa on mahdollista purkaa itsestään selviä oletuksia oppimisesta ja edistyksestä. Ulrich Beckin (1995, 17) mukaan ihmisten ja instituutioiden ajatuksia ja toimintaa hallitsevat yhä teollisen yhteis- kunnan itsestään selvät odotukset edistyksestä ja kehityksestä, joka on kuuro ja sokea omille seurausvaikutuksilleen ja tuottamilleen uhkille. Kun tässä tutkimuksessa osoitan, miten muutosta tehdään puheessa ja kielenkäytön yksityiskohdissa ja mitä markkinamuutos merkitsee julkisen sektorin työntekijöiden identiteettityön kannalta, teen samalla näkyväksi meneillä olevan muutoksen seurausvaikutuksia. Tutkimukseni luo näin edellytyksiä valintojen politiikalle, joka on tietoinen vaihtoehtoisista muutossuunnista ja tulkinta- ja merkityskehysten moninaisuudesta. Tällainen moninaisuuden osoittaminen tuo toimijatasolla myös vapauden ja valinnan mahdollisuuden. Toimija voi ymmärtää sosiaalista tilannetta kilpailevien puhekäytäntöjen kautta. Hän voi myös kieltäytyä merkityskehyksistä, joita hänellä on käytettävissään mutta joista hän haluaa ottaa välimatkaa (Davies \& Harre 1991/1992, 9).

【 opuksi haluan vielä esittää kysymyksen, mikä _roisi olla aikuiskasvatustutkimuksen tärkein haaste jälkimodernissa yhteiskunnassa. Tuo haaste ei liity ensinsijaisesti tuottavuuden ja kilpailukyvyn edistämiseen työelämässä, vaikka sekin on tärkeää. Mielestäni aikuiskasvatuksen tärkein tehtävä on auttaa ymmärtämään ja merkityksellistämään uudenlaista aikuisuutta, joka sijaitsee nuoruuden ja vanhuuden epäselvässä keski-iän välimaastossa. Aikuisuutta leimaa tällä hetkellä määrittelemättömyys, mikä näkyy esimerkiksi siinä, että 30-vuotias henkilö toteaa Tommi Hoikkalan (1993, 73) väitöskirjassa, että "mielestäni minä olen jo keski-ikäinen, neli- ja viisikymppiset ovat jo haudassa. Minusta tuntuu, että kaikki on jo takana päin, eletty, loppu. Edessä ei ole enää mitään”. Mielestäni aikuiskasvatuksen tutkijoiden tulisi Hoikkalan tapaan kysyä, miksi elämä tuntuu elämisen arvoiselta vain nuorena ja miksi vahvan aikuisuuden idea on jälkimodernissa ajassa himmentynyt.

Aikuisuus on muuttunut elinikäisen oppimisen yhteiskunnassa kypsästä ja valmiista aikuisuudesta jatkuvan keskenkasvuisuuden ja jatkuvan keskeneräisyyden hyväksymiseksi. Kun aiemmin oikea ammattimies ja ammattinainen saattoi luottaa ammattitaitonsa pysyvyyteen ja jatkuvaan kehitykseen, niin nyt hänen on suostuttava hyväk- 
symään uudenlainen tilanne. Hän on jatkuvasti pakotettu oppimiaan uusia asioita ja hylkäämään vanhoja ajattelu- ja toimintamalleja. Entisistä aikuisista on tullut keskenkasvuisia henkilöitä, jotka syrjäytyvät tietoyhteiskunnan luomien osallisuusmahdollisuuksien ulkopuolelle. Nyt aikuisuus ehkä tarkoittaakin sitä, että henkilö pystyy hallitsemaan monien vaihtuvien identiteettiensä kirjon ja elämäntilanteensa jatkuvan uudelleenmäärittelyn. Juuri tällaisen haasteen edessä olivat myös tutkimani julkisen sektorin ammattilaiset, virkamiehet ja kehittäjät. Tällaiseen uudelleenmäärittelytyöhön ja jatkuvuuksien rakentamiseen tarvitaan kipeästi aikuiskasvatuksen siirtymätiloja ja kulttuurista aikuiskasvatustutkimusta.

\section{Viitteet}

ALHEIT, P. (1996) Research and Innovation in Contemporary Adult Education. Kirjassa Papaioannou, S., Alheit, P., From Lauridsen, J. \& Salling Olesen, H. (Eds.) Community, Education and Social Change. Anogia Workbooks. Volume 2. Roskilde: RUC, 21-48.

BECK , U. (1995) Politiikan uudelleen keksiminen: kohti refleksiivisen modernisaation teoriaa. Kirjassa Beck, U., Giddens, A., Lash, S. Nykyajan jälkillä. Refleksiivinen modernisaatio. Tampere: Vastapaino.

CLARKE, J \& Newman, J. (1997). The Managerial State. Power, Politics and Ideology in the Remak- ing of Social Welfare. London: Sage.

COBURN, D. (1999). Professions in transition: Globalisation, neo-liberalism and the decilne of medical power. In Hellgerg, I., Saks, M., Benoit, C. (Eds.) Professional Identities in Transition. Monograph from the Department of Sociology No 71, Göteborg University. Södertälje; Almqvist \& Wiksell,139 $-156$.

DAVIES, B., Harre, R. (1991/1992) Contradiction in lived and told narratives. Research on Language and Social Interaction. Vol. 25, 1991/1992: 1-36.

HOIKKALA, T. (1993) Katoaako kasvatus, himmeneekö aikuisuus? Aikuistumisen puhe ja kulttuurimallit. Helsinki: Gaudeamus.

LEHTO, J. (1991) Professionaalisuuden ansa. Sosiaalilääketieteellinen Aikakauslehti. 28.vuosikerta, 3/1991, 181 - 185.

POLLITT, C. \& Bouckaert, G. (1995) Defining Quality in Pollitt, C. \& Bouckaert, G. (Eds.) Quality Improvement in European Public Services. Concepts, Cases and Commentary. London: Sage, 3 - 19.

WARD, S. C. (1995) The Making of Serious Speech: A Social Theory of Professional Discourse. Current Perspectives in Social Theory, Volume 15, 65-81.

LEKTIO PRAECURSORIA. Karin Filander puolusti väitöstutkimustaan Kehittämistyö murroksessa. Sitoutuminen, sopeutuminen ja vastarinta julkisella sektorilla 1990-luvulla 9. joulukuuta 2000. Tutkimus on ilmestynyt Tampereen yliopiston Acta Universitatis Tamperensis sarjassa numerolla 777. Vastaväittäjänä toimi professori Anja Heikkinen Jyväskylän yliopistosta.

Väitöskirjaa voi tilata Tampereen yliopiston julkaisujen myynnistä puh.(03) 2156055 ja taju@uta.fi. Kirja on luettavissa myös sähköisessä muodossa (Acta Universitatis Tamperensis 67) 